\title{
Paulus retro?
}

\author{
Professor, dr.phil. et theol. \\ Troels Engberg-Pedersen
}

\begin{abstract}
The article discusses claims made in a recent Danish book entitled Paul Plus - Four Prisms on Paul: Paul \& Paul, \& the Jews, \& Luther, \& Nietzsche (ed. Anna Vind; Copenhagen: Publications of the Faculty of Theology 30,2012). Against the contributors, who are basically presenting a traditional, Lutheran understanding of Paul in opposition to the 'New Perspective on Paul', it is first argued that not only was Paul a Jew: he also continued to see himself as a Jew and took the new Christ faith to be an eminently Jewish phenomenon; and secondly that a number of further features of a 'New Perspective' on Paul (he speaks ethnically about Jews and Gentiles, not about human beings vis-à-vis God; and he envisages an actual fulfillment of the Mosaic Law among Christ believers, not a continued state of being simultaneously 'justified and a sinner') follow directly from the first basic feature.
\end{abstract}

Key-words: Paul - the new perspective on Paul - Paul and Judaism Paul and the Law - Luther - Paul and sinfulness (simul iustus et peccator).

\section{Indledning: En ny eller luthersk Paulus?}

Fire teologer - Katrine Winkel Holm, Jesper Høgenhaven, Anna Vind og Carsten Pallesen -med tilknytning til Det Teologiske Fakultet i København har tilsammen skrevet en bog, hvis formål er at sætte spørgsmålstegn ved det såkaldt nye Paulusbillede. ${ }^{1}$ Specielt vil de slå et slag for den lutherske Paulus, som de ikke mener kommer til sin fulde ret i det nye Paulusbillede. Emnet er godt, og bogen fortjener et klargørende svar. I denne artikel vil jeg ikke forsøge at afgøre, om den ene tolkning af Paulus er bedre end den anden. Det ville kræve en mere omfattende gennemgang. Derimod vil jeg vise, hvordan for-

\footnotetext{
1. Anna Vind (red.), Paulus plus - fire prismer på den nye Paulus. Paulus \& Paulus, \& jøderne, \& Luther, \& Nietzsche (København: Publikationer fra Det Teologiske Fakultet 30, 2012), 168 s. Bogens første sætning lyder: "Ti-året for udgivelsen af bogen Den nye Paulus og hans betydning på Gyldendals Forlag i 2003 nærmer sig med hastige skridt." Og bogen forholder sig løbende til den nævnte bog (redigeret af denne artikels forfatter), hvor det nye Paulus-billede bliver omfattende præsenteret.
} 
skellige elementer i det nye Paulusbillede, som de fire forfattere er skeptiske over for, faktisk følger af en forståelse af Paulus' forhold til jødedommen, som er det centrale element i det nye Paulusbillede - en forståelse, som de fire forfattere efter mit skøn ikke har forstået helt til bunds.

Hvad er kernen i det nye Paulusbillede? Og hvad er kernen i det, som de fire forfattere savner? ${ }^{2}$ I bidragene til bogen kan disse to hovedspørgsmål samles i fire underspørgsmål:

(1) Hvad var Paulus' forhold til jødedommen? Hvor det nye Paulusbillede insisterer på, at Paulus var og blev jøde, dér ønsker man i Paulus plus at insistere på, at han gjorde op med jødedommen.

(2) Og så synden i to udgaver. For det første: Hvad bliver der i det nye Paulusbillede af tanken om menneskets oprør mod Gud: modsatningen mellem det, der kommer fra Gud, og det, der kommer fra mennesker?

(3) Og for det andet: Hvad bliver der i det nye Paulusbillede af tanken om, at mennesket er og vedbliver at være en synder, også når mennesket i Kristustroen er blevet gjort retfærdigt - det berømte simul iustus et peccator?

(4) Endelig: Hvad er overhovedet nyt i det såkaldt nye Paulusbillede? Har man ikke hørt det hele før, fx i liberalteologien fra for ca. 100 år siden? Og er der ikke snarere tale om, at fortalerne for det nye Paulusbillede bare vil indføre en anden teologi under en mere eller mindre falsk varebetegnelse?

Paulus plus gør indimellem meget ud af, at det ikke er helt klart, hvad det nye Paulusbillede går ud på, fordi forskere, der erklærer sig enige i det, også er indbyrdes uenige på en række punkter. ${ }^{3}$ Det kunne jo for så vidt være en god pointe, og man må medgive, at en person som James Dunn, der ligefrem er fadder til betegnelsen 'det nye perspektiv på Paulus', ${ }^{4}$ ganske vist er enig i den forståelse af Paulus' forhold til jødedommen, som indgår i det nye Paulusbillede (jf. under pkt. 1), men derimod ikke i den forståelse, der indgår i pkt. 2

2. Ret beset er det kun de tre første forfattere, der behandler de to spørgsmål. Carsten Pallesens artikel, "Djævelen som Guds advokat - Nietzsche, filosofien og Paulus" (Paulus plus 2012, 135-168) har sit fokus på det had-kærlighedsforhold til Paulus, som man ifølge den nyere Nietzsche-forskning finder hos Nietzsche. Det virker i sig selv helt overbevisende, men det er meget svært at se, at artiklen overhovedet forholder sig til spørgsmålet om ny eller gammel Paulus. Jeg lader den derfor ligge her.

3. Denne pointe er gennemgående hos Winkel Holm, som jeg skal vende tilbage til, men strejfes også fx af Høgenhaven (Paulus plus 2012, 46-47 n. 1 om "forskelligheden" hos nye Paulusforskere).

4. Dunn døbte det nye forskningsperspektiv i "The New Perspective on Paul”, i Bulletin of the John Rylands University Library of Manchester 65 (1983), 95-112. 
og $3 .{ }^{5}$ Men den sag handler nu mere om James Dunn end om den nye Paulus: Selv Dunn har ikke været i stand til helt at ryste sin nedarvede, systematiske og lutherske Paulusforståelse af sig. ${ }^{6}$ At føre Dunn i felten mod opfattelsen af, at der foreligger en samlet, ny Paulusforståelse, der er forskellig fra den tidligere, ville være det samme som at føre Käsemann i felten som argument for, at der slet ikke fandtes en gennemgående Paulusforståelse i den dialektiske teologi - bare fordi Käsemann ikke hele vejen var enig med Bultmann. Differentiering er på sin plads. Men man må også se hele skoven.

Hvad man så vil se, er, at Paulus plus gør helt ret i de facto at identificere de tre første af de nævnte fire punkter som dem, hvor vandene skiller. Hvis man mener, (1) at Paulus gjorde op med jødedommen, (2) eller at jødedommen ligefrem fremstår hos ham som et paradigmatisk eksempel på det mennesket iboende oprør mod Gud, (3) eller endelig, at det Kristustroende menneske fortsat og fundamentalt set er en synder, ja så kan man ikke hylde det nye Paulusbillede. Omvendt gælder det, at hvis man mener de tre nævnte ting, så befinder man sig på en god, traditionelt luthersk grund, der oven i købet (som Anna Vind overbevisende gør rede for) har sin klare rod hos Luther selv. Lad os se på disse tre temaer hver for sig.

\section{Paulus og jødedommen}

“Apostlen Paulus var jøde." Sådan indleder Jesper Høgenhaven sin artikel i bogen. ${ }^{7}$ Artiklen udmærker sig ved at give nogle meget præcise og oplysende referater af andre forskere. ${ }^{8}$ Interessant er det også, at

5. Dette gør Winkel Holm en del ud af (Paulus plus 2012, 20 og 33-34).

6. Et godt eksempel er Dunns afsluttende bidrag til forskningsprojektet 'Pauline Theology', der foregik ved de årlige møder i det amerikanske Society of Biblical Literature i årene 1986-1996. Pointen var her at forfølge udviklingen i Paulus' 'teologisering' gennem de enkelte breve taget for sig og i kronologisk rækkefølge. Ved den afsluttende session vakte James Dunn nogen opstandelse ved, da det kom til stykket, simpelthen at udnævne Romerbrevet til at være det samlede udtryk for Paulus teologi - et i sandhed traditionelt standpunkt.

7. "'For sine nådegaver og sit kald fortryder Gud ikke'. Paulus og den antikke jødedom" (Paulus plus, 2012, 41-79).

8. Fx referatet s. 47-51 af Krister Stendahls banebrydende artikel fra 1960 om Paulus og samvittigheden, der, som Høgenhaven rigtigt nævner, spillede en vigtig rolle som baggrund for det nye Paulusbillede; referaterne s. 52-54 og 54-56, dels af E.P. Sanders' banebrydende bog fra 1977 om Paul and Palestinian Judaism, dels af Jacob Neusners jødisk orienterede kritik af Sanders; og endelig - som en ret opsigtsvækkende alliancepartner i forsvaret for den lutherske Paulus - referatet s. 69-72 af Henrik Troniers læsning af "Kristus som værdiomvendende blik" fra bogen Den nye Paulus selv. 
Høgenhaven ser strukturelle ligheder mellem "Paulus' konstruktion af det sande Israel og de konstruktioner, der finder sted hos Filon af Alexandria og i Dødehavsteksterne fra Qumran” (s. 78). Altså de facto: Paulus var jøde.

Dér, hvor problemet opstår, er, når Høgenhaven så gør rede for Paulus' forholden sig til jødedommen i den række af centrale Paulustekster, som Høgenhaven tillige gennemgår: Fil 3,2-11, Rom 1,14, 2,17-29, 4,11-25, 6,3-8, 8,9-11, 10,1-4, 11,25-32, Gal 3,6-29, 4,8-9, 4,21-26 og 2 Kor 3,7-17, 4,16-18. Høgenhaven er på den ene side helt med på, at "[d]en antikke jødedoms tekster og forestillinger er den verden, Paulus skriver ud fra og ind i” (s. 78). Og han viser rigtigt, at Paulus arbejder med et begreb om 'den sande jødedom' eller 'det sande Israel', som er det, han argumenterer for. ${ }^{9}$ Han anerkender altså en 'kontinuitet' mellem Paulus og jødedommen. Men: Når han skriver om Paulus og jødedommen, sker det hele tiden ud fra et ganske bestemt perspektiv, som implicit forudsætter, at de to størrelser alligevel er skarpt adskilt. Paulus hører - trods al kontinuitet osv. - til et andet sted, nemlig i en størrelse, der hedder 'kristendommen', og han er dermed nærmest per definition adskilt fra den forudgående størrelse, 'jødedommen'. Hvad Høgenhaven her de facto gør (om end muligvis uerkendt) er at skrive om Paulus fra et meget senere perspektiv, nemlig fra det perspektiv, som Paulus er med til at formulere, men som endnu ikke var formuleret, da han skrev, og som egentlig gik imod alt, hvad han selv ønskede. Paulus ønskede ikke at rive en størrelse kaldet 'kristendommen' løs fra en anden størrelse kaldet ‘jødedommen'. Hvad han derimod ønskede, var - nøjagtigt ligesom Filon fra Alexandria og Qumran-samfundet - at konstruere den sande jødedom eller det sande Israel sat $\mathrm{i}$ et differentieret adskillende forhold til det Israel, som var repræsenteret ved de gængse jødiske institutioner og traditioner, først og fremmest templet og Moseloven. Man kan selvfølgelig udnævne det sidstnævnte Israel til simpelthen at vare 'jødedommen', så at man ved at adskille sig fra det adskilte sig fra jødedommen. Men det hverken gjorde eller ville Paulus. Hans særlige konstruktion af den sande jødedom var jødedom (i hans egen forestilling), men selvfølgelig en anderledes jødedom.

Årsagen til det sidste var, at der nu - inden for en jødisk ramme var sket noget afgørende nyt: Messias var kommet. Det forrykkede hele billedet og betød fx, at den 'retfærdiggørelse', der hidtil i den jødiske forestilling havde været knyttet til Moseloven, nu viste sig ikke

9. Således rigtigt (Paulus plus 2012, 78): "I en vis forstand former Paulus' polemik sig også som en ny konstruktion af den sande jødedom eller det sande Israel i modsætning til det 'Israel', som er repræsenteret ved gængse jødiske institutioner og traditioner". 
længere at være holdbar. Retfærdiggørelse og frelse var nu knyttet til Messias/Kristus og alene til ham. Dermed faldt retfærdiggørelsen ved Moseloven bort. Den havde tjent et formål, selv om den aldrig var nået helt i mål. Men nu var den blevet overhalet af en anden retfærdighed, der alene afhang af Kristus. ${ }^{10}$

Alt dette vedbliver imidlertid med at befinde sig inden for en jødisk referenceramme. Det er en jødisk Messias, der er kommet, og den frelse, som han muliggør, er en jødisk frelse. Høgenhaven understreger igen og igen, at Paulus placerer jødiske traditioner " $i$ en udpræget polemisk sammenhæng" (s. 78). Den "omformning af jødiske motiver", man møder hos Paulus, finder sted "i et bevidst polemisk opgør" (s. 56) og er præget af "polemisk tilspidsede, negative udsagn" (s. 63). I det hele taget optræder ordet 'polemik' (nemlig med jødiske positioner) igen og igen i artiklen. Og det er alt sammen rigtigt nok. Der er fuldt af polemisk opgør hos Paulus. Men: Opgøret er ikke med noget, der skal kaldes 'jødedommen', derimod med en bestemt form for jødedom, nemlig den, der fokuserede meget centralt på Moseloven. At det så de facto gælder "gængse jødiske institutioner og traditioner" i den antikke jødedom, er jo rigtigt nok. Det forhold, at Messias var kommet, måtte jo da uden tvivl have radikale konsekvenser. Men det er altså ikke noget, der placerer Paulus uden for noget, vi kan kalde 'jødedommen'. Paulus ville revolutionere jødedommen indefra.

Dette er altså det afgørende kritikpunkt, man må fremføre mod forståelsen af Paulus og jødedommen i Paulus plus: Jødedommen ses her konstant udefra, nemlig fra perspektivet af den 'anden' religion, der efterhånden udkrystalliserede sig: kristendommen. ${ }^{11}$ Just dette er - ifølge det nye Paulusbillede - forkert: Paulus ikke blot var jøde; han vedblev at være jøde, og den religion, han artikulerede, var fortsat et stykke jødedom. Paulus skal forstås indefra, som en del af jødedommen.

Hvorfor ser Høgenhaven og hans kolleger så sagen anderledes? Det er der flere grunde til. For det første er Paulus jo faktisk med til at formulere noget, der sidenhen blev (gjort) til en ny religion, kristendommen. Når vi læser Paulus, sker det netop ofte i en

10. Dette udtrykkes fx således i Gal 3,21-22 (DO 1992): "Er loven da imod Guds løfter? Aldeles ikke! For var der blevet givet en lov, som kunne gøre levende, så ville retfærdigheden også komme af loven. / Men Skriften har indesluttet alt under synd, for at løftet ved tro på Jesus Kristus kunne gives dem, som tror."

11. Nogle eksempler fra Winkel Holms afsnit "Er Paulus stadig jøde?" (Paulus plus 2012, 24-27): "Der ligger en markant distance i Paulus' formulering [i Gal 1,13 og 14], en klar markering af, at der er et skel mellem Guds kirke og jødedommen ... Paulus synes altså ikke at være tvivl om, at han har lagt jødedommen bag sig" (25, mine kursiver). "Kristusbegivenheden har betydet, at han helt fundamentalt har brudt med loven - og ifølge sig selv dermed med jødedommen" (26, mine kursiver). 
kristen sammenhæng. Hvad er da mere naturligt end også at tage kristendommen som udgangspunkt? Heroverfor gælder dog dette: Hvis man ønsker at læse Paulus i receptionshistoriens lys, kan det jo være meget rigtigt at læse ham på den måde. Blot skal man så gøre sig klart, at det faktisk er et meget senere receptionshistorisk lys, man så opererer med, nemlig lyset fra det, som Paulus blev til hos bl.a. Augustin og Luther. I det nye Paulusbillede derimod forsøger man, så vidt det overhovedet er gørligt, at komme tilbage til, hvad det alt sammen betød på Paulus' egen tid! ${ }^{12} \mathrm{Og}$ her gælder det altså, at Paulus var og blev jøde.

Der er en anden grund til, at Høgenhaven og hans kolleger læser, som de gør. Den hidrører fra en indre spænding hos Paulus selv: På den ene side var og blev han jøde, nemlig efter sin egen intention; på den anden side havde hans særlige konstruktion af 'den sande jødedom' et bestemt indhold, som gjorde, at den de facto - og altså imod Paulus' egen intention - sprængte jødedommen, dvs. åbnede op for den nye størrelse, som efterhånden blev til kristendommen. Hvad det drejer sig om her, er dels forholdet til ikke-jøder (hedninger), dels forholdet til Moseloven forstået som det, der for en traditionel forståelse (både jøders og ikke-jøders - men altså ikke Paulus' egen) ligefrem var med til at definere, hvad en jøde overhovedet var.

Hvad ikke-jøderne angår, var det Paulus' tanke, at de kunne tilslutte sig Kristustroen på nøjagtig samme måde, som jøderne både kunne og skulle. De kunne tro, at Messias var kommet; at han var død og opstået igen; at han ville komme tilbage; og at han så ville føre de troende hen til sig (i luften), hvorved de ville blive frelst. Hvad mere er: Ved fuldt og fast at tro alt dette og ved i dåben at modtage Guds ånd som en transformerende kraft i deres indre ville de allerede i dette liv kunne blive omformet også i 'etisk' henseende, så at de de facto nu ville kunne opfylde Moselovens bestemmelser. Men: De skulle ikke blive jøder i traditionel forstand, dvs. leve under Moseloven med blikket stift rettet mod at overholde den. For så ville deres blik blive forrykket fra det nye, der var sket (at Messias var kommet). Han alene skulle stå i fokus.

Hvad jøderne angår, skulle også de have tro på den nye Messias. De måtte for så vidt gerne fortsætte med at følge Moseloven, men kun hvis de var klar over, at Moseloven som sådan nu ikke længere spillede nogen rolle overhovedet. Det gjorde (også for dem) alene Messias.

12. Det er dette projekt, som ifølge Winkel Holm "vidner om en næsten positivistisk selvforståelse" hos denne artikels forfatter (Paulus plus 2012, 18). Personligt bekender jeg mig nu til al den hermeneutiske selvrefleksion, man kan opbyde hos fortolkeren - men sandelig også til forsøget på at komme bag om sin egen skygge i retning af en historisk rekonstruktion. 
Det betød så også, at jøderne på ingen som helst måde måtte insistere på Moseloven over for ikke-jøderne. For gjorde de det, ville de jo tillægge Moseloven i det mindste en vis betydning. Det er her, Paulus virkelig er polemisk (som i Galaterbrevet) mod de Kristustroende jøder, der fejlagtigt mente, at Moseloven dog også måtte betyde noget for ikke-jøderne. Nej, sagde Paulus: Intet! Det ene afgørende ligger et andet sted (i Kristus) - for ikke-jøderne og bestemt også for jøderne. Når Paulus er polemisk, er det altså ikke over for jødedommen som sådan (til forskel fra kristendommen), men over for de Kristustroende jøder, der immervæk også ville have Moseloven med ind i billedet. Moseloven var for så vidt stadig med inde i billedet i og med, at den nu blev opfyldt af de Kristustroende. ${ }^{13}$ Men Moseloven var ikke med inde i billedet som en 'etnisk markør', der skulle sætte skel mellem og dermed definere jøder og ikke-jøder. Som sådan var den sat ud af kraft. Også de Kristustroende ikke-jøder - der altså ikke var forpligtet på Moseloven - var sande jøder og del af det sande Israel.

Den indre spænding i Paulus' position er altså denne. På den ene side forstod han Kristustroen som en del af jødedommen, den sande jødedom. På den anden side konstruerede han Kristustroen - med dens eksklusive fokus på Kristus - sådan, at det, der traditionelt var med til at definere jødedom - nemlig forpligtelse på Moseloven - blev sat ud af kraft. Paulus var og ville altså være jøde, men han forstod Kristustroen på en sådan måde, at den de facto sprængte jødedommen. ${ }^{14}$ For ikkejøder skulle - uden at være forpligtet på Moseloven - være fuldgyldigt sande jøder, nøjagtigt lige så gode jøder som de Kristustroende jøder selv. Det er selvfølgelig denne spænding inde i hjertet af Paulus' hele koncept, der er med til at forklare, hvorfor der efterhånden med basis i Paulus udviklede sig en ny religion, kristendommen, der (nu) var løsgjort fra jødedommen. Men skridtet er altså ikke taget hos Paulus selv. Han var, vedblev at være og ville være jøde - ikke 'kristen'.

13. Se. Gal 5,13-14 (DO 1992): "Brødre, I blev kaldet til frihed. Brug blot ikke friheden som et påskud for kødet, men tjen hinanden i kærlighed. / For hele loven er opfyldt i det ene ord: "Du skal elske din næste som dig selv."” Og se Rom 13,8-10 (DO 1992 ændret): "Vær ingen noget andet skyldig end at elske hinanden; for den, der elsker den anden, har opfyldt loven. / Budene: „Du må ikke bryde et ægteskab; du må ikke begå drab; du må ikke stjæle; du må ikke begære," og et hvilket som helst andet bud, sammenfattes jo i dette bud: »Du skal elske din næste som dig selv.» / (For) kærligheden [nemlig når den faktisk foreligger] gør ikke noget ondt mod næsten. Kærligheden er altså lovens opfyldelse."

14. På det sidste punkt har Høgenhaven altså ret: "Det skal vise sig, at Paulus nok ser de Kristus-troende som de sande jøder men at han samtidig bestemmer den sande jøde på en måde, der sprænger rammerne for, hvordan man ellers i samtiden opfattede jødedommen" (Paulus plus 2012, 56). Problemet er blot, at Høgenhaven ikke har ret vedr. det første punkt (Paulus' fortsatte jødiskhed), og at han derfor ikke ser eller anerkender den spænding hos Paulus, der bliver resultatet. 
Jeg håber, at forskellen nu fremstår helt klart mellem en forståelse af Paulus' forhold til jødedommen af den type, der ligger bag alt, hvad Jesper Høgenhaven og hans kolleger siger om spørgsmålet, og så den forståelse, der er en integreret del af det nye Paulusbillede. Hvem har så ret? Det kan vi ikke afgøre her, og det har som nævnt heller ikke været anliggendet. Det vigtige er at forstå, hvori selve forskellen består. Den forståelse savner jeg fuldstændig i Paulus plus.

Ud af denne forståelse af Paulus' forhold til jødedommen springer så endnu et punkt, som er med til at definere forskellen mellem gammel og ny Paulus. Punktet ligger lige på overgangen til det spørgsmål, der skal tages op i det næste afsnit. Punktet er følgende: Når Paulus taler om jøder, hører man det i det nye Paulusbillede sådan, at han taler om en bestemt etnisk gruppe (nemlig jøderne) til forskel fra andre etniske grupper (nemlig ikke-jøder). I det gamle Paulusbillede hører man det helt anderledes. Her taler Paulus om mennesker i modsætning til Gud. Altså horisontalt hos de nye og vertikalt hos de gamle. Et godt eksempel (se næste afsnit) er det, når Høgenhaven skal gøre rede for forskellen i Rom 10,3 mellem "Guds retfærdighed" og "deres" (nemlig jødernes) "egen" retfærdighed. Som Høgenhaven rigtigt refererer, forstår James Dunn det på god ny-paulinsk vis sådan, at "deres egen' retfærdighed ikke ... skal forstås som en retfærdighed baseret på 'egne præstationer' eller 'egen indsats' men derimod som en retfærdighed, der er jødernes 'egen' i den forstand, at den eksklusivt tilhører jøderne (i modsætning til hedningerne)" (s. 76). Men Høgenhaven kommenterer så: "Imod Dunns tolkning taler imidlertid den tydelige antitese imellem den retfærdighed, der er Guds, og den, der siges at være 'deres egen'. Modsatningen er imellem Gud og mennesker, ikke imellem to forskellige 'etniske' grupper, jøder og hedninger" (s. 76, mine kursiver). Dette er netop forskellen mellem gammelt og nyt: Den gamle tolkning søger hele tiden en grundlagsforståelse af forskellen mellem Gud og mennesker, som ikke nødvendigvis er bundet til nogen konkret situation, og den er i den helt præcise forstand decideret 'teo-logisk'; den nye derimod tænker mere konkret og kontekstuelt og søger efter den præcise betydning i den konkrete situation, som teksten afspejler. Men også det er selvfølgelig teologisk af den simple grund, at alt hos Paulus også vedrører Gud og hans konkrete indgriben. Om den ene eller den anden forståelse er rigtig, skal som sagt ikke afgøres her. Det vigtige er, at forskellen mellem dem bliver ultraklar. Vil man læse Paulus abstrakt og alment? Eller vil man læse ham konkret og med et skarpt fokus ind i en konkret situation? ${ }^{15}$

15. Det siger sig selv, at dette ikke er noget eksklusivt alternativ. Men den traditionelle læsemåde, der gradvis udviklede sig efter Paulus selv, tenderer mod en forholdsvis eksklusivt abstrakt forståelse, netop fordi den konkrete problemstilling 


\section{Synden: Mennesket 'vil selv' $i$ et oprør mod Gud}

Pkt. 2 ovenfor vedrører den menneskelige side af, hvad der hos Jesper Høgenhaven hedder "det uundgåelige sammenstød imellem Guds og menneskers virkelighed" (s. 79). Punktet er ikke helt så eksplicit tematiseret i Paulus plus som det første punkt om forholdet til jødedommen. Men neden under det hele er det sikkert mindst lige så vigtigt. Hvad mere er: Det er denne artikels påstand, at selve logikken i forståelsen af Paulus' forhold til jødedommen i det nye Paulusbillede peger direkte imod den af Høgenhaven formulerede forståelse. Jeg har formuleret punktet sådan, at det handler om, at mennesket 'vil selv' i et mere eller mindre eksplicit opgør med tanken om at følge Gud. Lad mig anføre nogle citater fra Høgenhaven, der viser forskellige aspekter af dette tema.

Fortjeneste. I Fil 3,7 taler Paulus om en "gevinst" (kerdos eller i flertal kerdê), som han på grund af Kristus nu regner for et "tab" (zêmia). Høgenhaven oversætter frejdigt kerdê ("gevinster") som "fortjeneste" (s. 43), men parafraserer dog på næste side udtrykket som "'fortjeneste'/'vinding'”. Lige lidt hjælper det dog: “... på et underliggende plan fornemmes den fundamentale modsætning imellem Gud og mennesker" (s. 44). Så vidt jeg kan se, møder vi her en helt traditionel forståelse af 'fortjeneste': at 'jøden' mener at kunne gøre sig fortjent til Guds frelse; 'jøden' vil så at sige selv. Men det er der intet i selve teksten, der lægger op til. 'Gevinster' er 'fortrin' (sammenlignet med, hvad man finder hos ikke-jøder NB), som jøden Paulus havde og for så vidt stadig har i og med, at han blev omskåret på ottendedagen osv. (Fil 3,5-6). Det kan da ikke være noget, hvormed 'han selv' kan have gjort sig 'fortjent' over for Gud. Tværtimod. Med alle disse 'gevinster' eller 'fortrin' viser Paulus jo netop, at han er lydig over for de af Gud givne forordninger. ${ }^{16}$

'Min egen' versus Guds. Et par steder (s. 44 og 76) diskuterer Høgenhaven - med fuldt belæg hos Paulus (Fil 3,9 og Rom 10,3) - modsætningen mellem 'min egen' retfærdighed og Guds. I Fil 3,9 er det dog 'min (egen)' = Paulus' egen, hvorimod det i Rom 10,3 er 'deres egen' = de traditionelt forstående jøders. Høgenhaven ser forskellen som en modsætning mellem "det, der kommer fra Gud", og "det,

om forholdet mellem jøder og ikke-jøder ikke længere var brændende på samme måde som tidligere.

16. Tanken om fortjeneste dukker op igen hos Høgenhaven i forbindelse med Rom 4,1-5 (Paulus plus 2012, 61), uden at den underliggende teologiske pointe dog bliver rigtigt udarbejdet. Heller ikke denne passage skal efter min mening forstås sådan, at der ville have været noget som helst odiøst i det, hvis Abraham havde fået sin 'løn' som 'fortjent'. Nu er det bare ikke det, Skriften siger. 
der kommer fra mennesker" (s. 76), men diskuterer i øvrigt ikke, hvordan man kommer til den forståelse. Det er svært at se andet, end at Høgenhaven her igen forudsætter den traditionelle forestilling om en modsætning mellem, hvad mennesket 'selv vil' og pukker på som sin 'fortjeneste' - og så hvad Gud vil. Men en sådan forståelse ligger langtfra lige for.

Rom 10,3-4 kan parafraseres således: 'Da de er uvidende om Guds retfærdighed [= den, der nu er kommet med Kristus] og (i stedet) søger at fastholde deres egen retfærdighed [= den, de tidligere har haft, og som bestemmer deres identitet i forhold til andre mennesker], så har de ikke underordnet sig under Guds retfærdighed [= den, Kristus bragte]. Men Kristus betyder enden på Moseloven, til retfærdighed for enhver, som tror [inkl. ikke-jødiske Kristustroende].' Her betyder 'deres egen retfærdighed' 'den traditionelt jødiske retfærdighed', som sætter det skel mellem jøder og ikke-jøder, som nu er sat til side, da Kristus har sat Moseloven ud af kraft, så der bliver mulighed for retfærdighed for enhver, der tror. Der er i dette intet om et direkte modsætningsforhold mellem mennesker og Gud. Snarere er det tanken, at jøderne ikke har fattet 'Guds retfærdighed' (dvs. Kristus) og derfor holder fast ved den tanke om retfærdighed, som definerer dem selv i modsætning til ikke-jøder. Det er jo netop åbningen af jødedommen over for ikke-jøder, som er Paulus' tema. ${ }^{17}$

Eller tag Fil 3,8-9. Paulus vil "vinde Kristus og findes i ham, uden at have min egen retfærdighed, den fra loven, men den gennem Kristustro, retfærdigheden fra Gud ved troen”. Også her handler det om at tage imod den nye retfærdighed, der kommer direkte fra Gud (nemlig ved Kristus), og dermed at vende ryggen til den forestilling om retfærdighed, som man tidligere forstod som definerende for ens egen identitet - sådan som Paulus just har beskrevet det i 3,4-6. Altså: ikke den gamle retfærdighed, som var med til at definere mig, men derimod den nye, som Gud nu har etableret, så at sige senkrecht von oben. Der er ingen tvivl om, at Paulus her vil sige, at Gud har etableret den nye retfærdighed ved et pludseligt og radikalt indgreb. Men der er ingen som helst grund til at mene, at det så står i modsætning til noget andet, som mennesket 'selv' har villet etablere i modsætning til Gud. Tværtimod var retfærdigheden af loven jo også noget, der

17. Der er en helt central pointe her for min egen forståelse af Paulus. Når han kontrasterer en forkert 'brysten sig' (kauchêsis) med den korrekte 'brysten sig', som er rettet mod Kristus og bedst kan forstås som en 'jubel over Kristus' (se fx 1 Kor 1,29-31), er den kontrasterede 'brysten sig' ikke vendt mod Gud, men mod andre mennesker, nemlig ikke-jøder, som ikke har det samme gode forhold til Gud, som man selv har. Man 'bryster sig' over Gud (over for andre), ikke direkte over for ham. 
var etableret af Gud. Gud gav loven. Men nu er der altså - og stadig inden for jødedommen - sket noget yderligere.

Man kunne blive ved på denne måde. Høgenhaven gør med rette meget ud af de både kosmologiske og antropologiske modsætninger hos Paulus, fx mellem kød og ånd. Men det er langtfra givet, at de skal forstås, som det traditionelt sker - og som det også sker her, når Høgenhaven skriver følgende (s. 75, mine kursiver og andre tilføjelser): 'Kød og ånd er markante modsætninger, idet 'kød' står for den forgængelige, dødelige og materielle verden [rigtigt!], men også tenderer i retning af [?!] det mod Gud oprørske eller opsatsige [!], der [med et citat fra Qumran:] 'ikke kender forskel på godt og ondt'”. Her er der efter min mening kun tale om en overtagelse af traditionelle, teologiske forståelsesmåder, ikke om det nødvendige, omhyggelige forsøg på at forstå på ny.

Jeg har specielt under dette punkt forholdt mig til Jesper Høgenhavens artikel, fordi han skriver så præcist og klart og virkelig forsøger at læse sine Paulustekster. Så meget mere interessant er det, at der indimellem dukker underliggende forståelseskategorier op, som vi alle ved afspejler en traditionel luthersk forståelse - men uden at de bliver helt direkte adresseret. Det er de facto lige præcis dem, det nye Paulusbillede sætter spørgsmålstegn ved, ikke fordi det i sig selv skulle være noget mål at gøre op med Luther (hvorfor skulle det dog det?), men fordi man simpelthen ikke længere kan finde dem hos Paulus, nu da forståelsen er blevet frisat til at finde en anden Paulus: en mere konkret historisk Paulus, der slet ikke vil bryde med jødedommen og bestemt ikke ser 'jøden' som et paradigmatisk eksempel på 'opsætsighed' mod Gud.

\section{Synden: Mennesket forbliver en synder over for Gud}

Dette tema indgår i den berømte tanke om, at det Kristustroende menneske er simul iustus et peccator, på en og samme tid retfærdig(gjort) og en synder. Som det fremgår af Anna Vinds lange, lærde og grundige artikel i bogen, ${ }^{18}$ er dette tema hos Luther overordentlig vidtforgrenet, så det indgår som én central del af Luthers samlede forestilling om det kristne menneskes forhold til Gud. Vinds anliggende er ikke direkte at diskutere den nye Paulus, men at "vise, hvordan træk fra den nyere Paulusforskning har påvirket Lutherforskningen, og at efterprøve om denne 'nye' Lutherforsknings resultater er overbevisende" (s. 134, jf. s. 85). Som repræsentant for den nye Lutherforskning har hun valgt

18. "Den nye Luther" (Paulus plus 2012, 81-134). 
Aarhus-teologen Bo Kristian Holms bog Gabe und Geben. Das Verhältnis zwischen Reziprozität und reformatorischer Rechtfertigungsleh$r e .{ }^{19}$ Vind giver en fyldig og solidarisk redegørelse for Holms læsninger og argumenterer så med omfattende basis hos Luther selv for, at disse læsninger i bestemte henseender er mangelfulde. Men hvordan er alt dette så relevant $\mathrm{i}$ forhold til det nye Paulusbillede?

I Vinds gennemgang støder man bl.a. på følgende sætning: "Enhver lære om, at de døbte og bodfærdige ingen synd har bortset fra en svaghed eller en fristelse, er fordærvelig, understreger Luther (WA 2, 495,15-16)" (s. 107). Omvendt gælder det, som Vind citerer (s. $107 \mathrm{n}$. 68) fra WA 2, 497,13-14: "Simul ergo iustus, simul peccator." At dette ikke er en småting, fremgår med al ønskelig tydelighed af hele resten af Vinds artikel. Herhen hører fx den centrale tanke om Gudsrigets skjulthed, som betyder, at det kun kan erfares i troen, dvs. tros: "Guds og Jesu nåde og fred ... er åndelig og hemmelig. Nåden fjerner synderne og freden beroliger og glæder hjertet, men det hele finder sted $i$ det skjulte" (s. 115, min kursiv): "den indre fred er usynlig og ufølelig undtaget for troen" (s. 115). Thi: "korset alene er vor teologi”, som Vind citerer (s. 116). Mennesket skal derfor "erfare, at det intet er i sig selv og derfor ikke skal bygge sit liv på sig selv" (s. 118). "Det, som mennesket [overhovedet] erfarer, er tilintetgørelsen [husk: en synder], men den samtidige tilblivelse [trods alt jo også: retfærdig] er skjult og ufølelig og (for det meste) kun synlig for troen" (s. 120, mine skarpe parenteser). Dette passer alt sammen godt med "den troendes ønske om mere trængsel og mere kors" (s. 122). For kun på den måde kan man føle nogen som helst vished og glæde over - eller i det mindste et vist håb om - Guds frelse. Perspektivet udstrækker sig også til spørgsmålet om, hvordan man konkret skal leve her og nu, hvad man altså skal gøre. Her er svaret nemlig dette: "Buddene og formaningerne [i Bibelen] er ikke opfordringer til aktivitet, men opfordringer til passivitet, til at give plads for Gud. ... Gode gerninger skal sandelig gøres og åndens træ skal bære frugt [jf. Gal 5,22] ..., men det skal ske i korsteologisk forstand" (s. 129-130, mine skarpe parenteser), hvilket Vind så lader Luther udfolde i følgende prægtige citat (s. 130):

hvor Skriften påbyder at der gøres en god gerning, skal du forstå det således, at den forbyder [!] dig at gøre en god gerning, fordi du ikke kan, men ligesom du helligholder sabbatten for Gud, skal du være død og begravet og tillade, at Gud virker i dig. Men her kan du aldrig komme hen undtagen gennem tro, håb og kærlighed, dvs. ved din død inklusiv alt det, der tilhører dig.

19. Berlin: de Gruyter 2006. 
Jeg har citeret lidt mere udførligt fra Vinds instruktive gengivelse af Luther for at vise, hvor langt dette ligger fra den genuine Paulus, uanset hvor gerne man vil læse ham med lutherske briller. Kors og synd og bodfærdighed - det er virkelig teologi, så det batter, fordi dets hele formål er at sige: 'Gud alene' eller 'Gud er alt, jeg er intet'. Men man må desværre insistere på, at hele denne synsmåde ligger milevidt fra, hvad man finder hos Paulus selv. Hos Paulus er der bestemt også en insisteren på 'korset', fx i 1 Kor 1-2, og på korsets betydning for 'mig', fx i Gal 2,19-20. Men hos Paulus betyder 'kors' altid 'kors og opstandelse'. Jesus døde på korset og stod op igen. Den Kristustroende er 'korsfæstet med Kristus for verden' (jf. Gal 2,19 og 6,14) $o g$ allerede nu - gennem dåben - fyldt i sin krop af den ånd, der ved tidernes ende vil betyde opstandelse. Dette skifte er endda så radikalt, at selv om mennesket nok fortsat lever i kødet, så er det ikke længere kødeligt, og altså heller ikke en synder. For som der står i Gal 5,16: Vandr efter ånden, så vil I visselig ikke følge kødets begær. ${ }^{20}$ De kristustroende har ånden. De lever efter ånden. De bliver så i Paulus' mange formaninger (parænesen) mindet om, at de har ånden, for at de fortsat kan 'træne' den i deres åndelige fitnesscenter, så den ikke bliver slap. ${ }^{21} \mathrm{Og}$ når de på den måde holder sig i form, vil de også udfolde den i praksis. Så vil de - sikkert som amen i kirken - ikke følge kødets begær. Her er kødet virkelig kun, som Luther ikke ville have det, en fristelse eller trussel - om overhovedet det.

Dette er igen konkret, præcist og håndgribeligt. Og det kaster sig ikke ud i tankemæssige krumspring, hvis formål er at sikre Guds majestæt. For den er der ingen, der i Paulus' verden har sat spørgsmålstegn ved. Det hele kommer - hvis man nu vil stille det spørgsmål - fra Gud. Men det udelukker sandelig ikke, at mennesket også kan gøre noget, ja sådan set alt: handle eller lade være.

Det er klart, at man kunne diskutere i tekstlig detalje, om denne forståelse af Paulus nu er den bedste. Her har pointen kun været denne: Jo mere man med Anna Vind udfolder, hvad det er, Luther vil sige, desto mere tydeligt bliver det, at man dermed fjerner sig fra Paulus (i hvert fald ifølge det nye Paulusbillede). Men det gør jo heller ikke noget som helst. Tværtimod er det da netop interessant at se, hvordan Luther ind i sin egen historiske situation konstruerer en

20. Dette er et af de steder, hvor DO 1992s oversættelse er fatalt forkert: "I skal leve i Ånden og ikke følge kødets lyst." Hvordan kan det være, at denne oversættelse, som simpelthen ikke lader sig begrunde i det græske, stadig kan findes hist og her - om ikke fordi den harmonerer bedre med en luthersk læsning af Paulus?

21. Jeg gør her brug af en metaforik, som min Aarhus-kollega Kasper Bro Larsen har foreslået til forklaring af parænesens pointe. Bortset fra det rent stilistiske mener jeg, at denne metaforik bringer parænesens logiske form hos Paulus rigtig godt til udtryk. 
teologi, som har sit tydelige afsæt i Paulus - men som jo ikke af den grund behøver være identisk med Paulus' egen.

Argumenterer jeg så omvendt for, at vi nu både skal forsøge at rekonstruere Paulus' egne positioner så godt, det videnskabeligt lader sig gøre - og så også skal overtage netop de positioner og gøre dem til vores egne? Selvfølgelig ikke. Vi kan sagtens lade os inspirere teologisk af, hvad vi måtte finde hos Paulus, men vi kan af mange gode grunde ikke overtage det direkte. (Her havde fx Rudolf Bultmann fuldstændig ret.) Og det skal vi heller ikke forsøge på. Her gælder det tværtimod om at holde to ting adskilt: den videnskabelige undersøgelse af et antikt fænomen (Paulus) og selvstændig, moderne refleksion over de samme temaer, som bliver behandlet i det antikke materiale.

Det fører mig direkte til en kort drøftelse af det sidste af de fire hovedspørgsmål, som rejses i Paulus plus: det nye Paulusbilledes status i forhold til ældre fortolkninger.

\section{Intet nyt under solen?}

Under denne rubrik hører en række lidt forskellige spørgsmål og påstande, som dukker op løbende i bogen, men som fremtræder særlig klart i Katrine Winkel Holms artikel. ${ }^{22}$

Ét tema er den allerede nævnte påstand om, at fortalerne for det nye Paulusbillede er så uenige indbyrdes, at selve betegnelsen nærmest er falsk varebetegnelse. Fx konstaterer Winkel Holm, "at repræsentanterne for denne forskningsretning er forbløffende uenige i mange afgørende dele af Paulus-forskningen" (s. 16). Man får ligefrem fornemmelsen af, at der sådan slet ikke findes nogen ny Paulus. I stedet er der i virkeligheden tale om en term, der skal dække over noget helt andet, nemlig et forsøg på at markedsføre en alternativ teologi.

Ikke desto mindre tilbageviser de tre første artikler i Paulus plus med fynd og klem selv påstanden om, at der slet ikke er noget nyt, der binder repræsentanterne for det nye Paulusbillede sammen i forhold til tidligere tiders Pauluslæsning. Det sker, når de tre forfattere tager fat på lige præcis de tre hovedtemaer, jeg har behandlet ovenfor. Når Winkel Holm fx stiller og diskuterer spørgsmålet "Er Paulus stadig jøde?" (s. 24-27), så viser hun jo ganske tydeligt, at hun er fuldt på det rene med, at det spørgsmål er et springende punkt bag det nye Paulusbillede. På samme måde selvfølgelig med Jesper Høgenhavens artikel, som jo simpelthen handler om dette spørgsmål. Og endelig

22. "Til frihed har Kristus befriet jer'. Ny og gammel Paulus i Galaterbrevet" (Paulus plus 2012, 13-39). 
siger Anna Vind (og altså fuldstændig med rette): "Et af hovedsynspunkterne blandt fortalerne for Den Nye Paulus har været, at Paulus var og forblev jøde hele sit liv" (s. 81). De tre forfattere ser altså de facto det nye i det nye Paulusbillede, dog uden helt at begribe radikaliteten i den ændrede forståelse af Paulus' forhold til jødedommen. Nøjagtigt det samme gælder så også om de to andre hovedtemaer. I selve deres 'attack' viser de tre forfattere altså med fuldstændig klarhed, at de har et 'target'. Og det er så simpelthen det, der hører ind under og definerer det nye Paulusbillede.

Et andet tema hos Winkel Holm er, "at de synspunkter, de [nemlig "bannerførerne" for "den såkaldt nye Paulusforskning" og "deres mange løjtnanter"] forfægter, ikke er særligt nye” (s. 16). Hun kan derfor "slå fast, at der i den såkaldte nye tilgang til Paulus i høj grad er tale om genoptagelse eller genopdagelse af tidligere tiders Paulusforskning, der bliver brugt som skyts mod Bultmannskolens positioner" (s. 22). Ja, hun kan ligefrem "iagttage, hvordan pendulet svinger i Paulusfortolkningen: Først Wrede og Schweizers [KWH mener 'Schweitzers'] liberalteologiske pointer, så Bultmannskolens eksistentiale interpretation, og nu tilbage til Wrede og Schwei[ $\mathrm{t}$ zer med en markant afvisning af Bultmann-skolen" (s. 22). ${ }^{23}$

Winkel Holm har bestemt en pointe her, men efter min mening er der to forhold, som afgørende ændrer på hendes underliggende påstand om, at det hele bare handler om, at fortalerne for det nye Paulusbillede vil have en anden teologi. Det første forhold er, at den såkaldte liberalteologi, i hvert fald som den her repræsenteres af eksegetiske foregangsmænd som William Wrede og Albert Schweitzer, uomtvisteligt i sig selv var udtryk for en styrket videnskabeliggørelse af studiet af Det Nye Testamente. Denne videnskabeliggørelse blev videreført i Bultmannskolen, med afsæt hos Bultmann selv, som jeg i øvrigt plejer at kalde det 20. århundredes største NT-ekseget. ${ }^{24}$ Men den blev også kombineret med en - i sig selv fascinerende og fremragende - hermeneutisk og teologisk bevidsthed, ikke mindst i Bultmanns egen eksistentiale interpretation, som de facto låste nogle af de grundlæggende elementer i Paulusforståelsen fast på en måde, som stillede sig hindrende i vejen for en yderligere videnskabeliggørelse. Det er disse elementer, som det nye Paulusbillede har følt sig tvunget til at gøre op med i Bultmannskolen.

23. Også Vind er tiltalt af denne tanke om pendulet: "Fortolkningernes historie er ikke fremadskridende, men cirkulær" (Paulus plus 2012, 81).

24. Det er fx denne videnskabeliggørelse, der ligger bag Bultmann-eleven W.G. Kümmels fortsat helt overbevisende tolkning af Rom kap. 7 fra 1929, en tolkning, som Bultmann holdt fast $\mathrm{i}$, og som Winkel Holm selv tilsluttede sig i begyndelsen af 1990'erne - men som hun nu desværre lægger afstand til i følgeskab med James Dunn (Paulus plus 2012, 38). 
Det andet forhold gælder så relationen til fx Wrede og Schweitzer. På den ene side er det rigtigt, at det nye Paulusbillede henter inspiration hos dem. På den anden side gælder det så immervæk, at nogle af de helt centrale fortolkninger hos Wrede og Schweitzer fortsat blev stående i en forestilling om en radikal modsætning mellem kristendom og jødedom hos Paulus. På et tidspunkt overvejede jeg selv, om man ikke skulle oversætte Wredes fremragende, lille folkebog Paulus fra 1907 til dansk..$^{25}$ Men jeg opgav tanken, da jeg kunne se, at man ville være nødsaget til at tilføje så mange kvalificerende noter, at resultatet ville blive uoverskueligt.

Pointen er her, at uanset hvad Winkel Holm vil give indtryk af, så er der de facto tale om en fortsat videnskabeliggørelse af arbejdet med Paulus, som er afspejlet i det nye Paulusbillede. Det betyder på ingen måde, at alt i dette billede er korrekt. Fx er jeg selv meget forbeholden over for tanken om, at der fra og med Kristusbegivenheden ifølge Paulus skulle være to adgange til frelsen, en for jøder, som ud over at bekende sig til Kristus bare skulle fortsætte med at leve efter Moseloven, og en for ikke-jøder, som nu havde adgang til den jødiske frelse gennem Kristus alene, men altså uden at leve efter Moseloven. ${ }^{26}$ Her tror jeg, man går fejl af radikaliteten hos Paulus, som for mig at se betød, at det nu alene var Kristus, det kom an på - både for jøder og ikke-jøder. Jøder kunne måske nok fortsætte med at følge diverse forskrifter i Moseloven, man da kun som noget, der i forhold til det egentlige (Kristustroen) var et adiaphoron, dvs. i sig selv helt og aldeles 'ligegyldigt'. ${ }^{27}$ Tilbage står, at det kun er ved at afprøve sådanne tolkninger, der virkelig tager den jødiske Paulus alvorligt, at man kan nærme sig den mest adækvate forstålse af Paulus selv.

\section{Konklusion: Den afgorende forskel}

I denne artikel om Katrine Winkel Holms, Jesper Høgenhavens og Anna Vinds forsøg på at give et luthersk inspireret svar på det nye Paulusbillede har jeg, som det er fremgået, ikke forsøgt at gøre det, man i sidste ende skulle, og som i hvert fald de to første forfattere på hver deres måde gør, nemlig at gå i clinch med Paulus selv for at

25.112 s., trykt i 20.000 eksemplarer i en serie med den forjættende titel Religionsgeschichtliche Volksbücher für die deutsche christliche Gegenwart.

26. Denne særlige gren af det nye Paulusbillede vinder i disse år mere og mere frem under selvbetegnelsen 'the new new perspective on Paul' (således Magnus Zetterholm i Lund).

27. Det er denne forståelse, der lægger Paulus uhyre tæt op ad den stoiske forståelse af forholdet mellem 'det gode', som er én og kun én ting, og håndteringen af 'goderne', som i virkeligheden kun er adiaphora. 
undersøge, om den ene eller den anden (type) forståelse er den mest adækvate. I stedet har jeg brugt pladsen på at trække selve forskellen mellem den gamle og den nye Paulus så klart op, som det overhovedet lader sig gøre. Årsagen er, at jeg - kommende fra det nye Paulusbillede - synes, jeg må konstatere en ret grundlæggende mangel på forståelse af implikationerne af det, som uden tvivl er det afgørende element i det nye Paulusbillede: at Paulus var, forblev og ville forblive jøde. Paulus så den nye Kristustro som den sande jødedom, dvs. som det, jødedommen egentlig ville og skulle være. Deraf følger så en række andre theologoumena, der bl.a. betød en omkalfatring af alt det traditionelt jødiske. Moseloven som sådan var afskaffet som frelsesvej. Men årsagen var, at i og med Kristustroen (og åndsmodtagelsen) blev Moseloven nu endelig opfyldt, hvad den ikke kunne blive før. Når man derfor - uanset om man var etnisk jøde eller ej - bekendte sig til Kristustroen med alt, hvad deraf fulgte (åndsmodtagelse og åndspraksis), ja så var man helt konkret og nede på jorden den sande jøde, en rigtig jøde, som nu endelig gjorde, hvad Gud hele tiden havde villet, at man skulle gøre: Moselovens centrale indhold. Den tragiske dimension i hele dette koncept, som også forklarer, hvorfor Kristustroen fra og med Paulus så faktisk udviklede sig til en selvstændig religion, var den, at Paulus - i sin radikale bekendelse til Kristus alene - også nedskrev værdien af det, der traditionelt både før og efter Paulus ligefrem har defineret, hvad en jøde er, nemlig forpligtelsen på Moseloven. Selv om Moseloven som nævnt blev opfyldt i Kristus, var den fuldstændig 'beside the point' for ikke-jøder - og allerhøjest et adiaphoron for jøder. Lige præcis den påstand kunne den traditionelle jødedom ikke acceptere.

Paulus var, forblev og ville forblive jøde. Kristendommen eksisterede ikke for ham som en fra jødedommen adskilt størrelse. Af denne påstand følger hele resten: at han grundlæggende i sit opgør med Moseloven taler konkret etnisk om forholdet mellem jøder og ikke-jøder, og ikke abstrakt om forholdet mellem mennesket og Gud; at han aldrig ser jødedommen som et paradigmatisk eksempel på en mennesket iboende syndighed, der udspringer af selvhævdelse i opsætsighed mod Gud el. lign.; at Moseloven i og med Kristus nu vil blive opfyldt, og det Kristustroende menneske dermed ikke længere er en synder. Når Grundtvig i 1824 (vidunderligt) skrev "O, lad mig nedknæle så dybt i mit ler, at Gud mig kun ser!", ja så talte han faktisk ikke, som apostlen Paulus gjorde. 